\title{
Online Learning Challenges in Schools During the Pandemic COVID-19 in Indonesia
}

\author{
Dwi Sogi Sri Redjeki ${ }^{1}$, Agustinus Hermino ${ }^{2} \&$ Imron Arifin $^{3}$ \\ ${ }^{1}$ Universitas Sari Mulia, Banjarmasin, Indonesia. E-mail: rinacubby72@gmail.com \\ ${ }^{2}$ Consultant in Educational Management, Indonesia. E-mail: agustinus_hermino@yahoo.com \\ ${ }^{3}$ Universitas Negeri Malang, Malang, Indonesia. E-mail: imron.arifin.fip@um.ac.id \\ Correspondence: Agustinus Hermino, Consultant in Educational Management, Indonesia. E-mail: \\ agustinus_hermino@yahoo.com
}

$\begin{array}{lcc}\text { Received: July 12, 2021 } & \text { Accepted: August 11, } 2021 & \text { Online Published: September 19, } 2021 \\ \text { doi:10.5539/ass.v17n10p53 } & \text { URL: https://doi.org/10.5539/ass.v17n10p53 }\end{array}$

\begin{abstract}
The purpose of this research is to provide information to the Government of Indonesia in particular and observers of education in general regarding the challenges of online learning in schools in remote areas in Indonesia so that there is mutual attention from educational stakeholders to pay attention to students in remote areas to retain their rights in education. This research methodology is qualitative, using the result of previous relevant researchs that support in writing of this research. The research findings include: 1) the importance of the role of school principals as implementers of government policies; 2) teachers' strategies in implementing online learning that are easily understood by students; 3 ) the importance of the role of parental assistance during online learning; and 4) Regional Government policy strategies for the success of online learning, especially in remote areas. The recommendations of this research are: 1) adjusting online learning based on local conditions; 2) the existence of task forces in the regions to help the online learning process run smoothly; 3) monitoring and evaluation; 4) broad autonomy for school principals to innovate; 5) teacher training program to support the online learning process; 6) the existence of cooperation between the government and the private sector in the telecommunications sector; 7) face-to-face learning for students who do not have telecommunication equipment.
\end{abstract}

Keywords: role of school principal, learning strategy, online learning, remote area society

\section{Introduction}

The Covid-19 pandemic has affected the education system in the world and especially in Indonesia. Starting from March 2020 until now the Indonesian Government through the Ministry of Education and Culture has been working and always trying to issue policies in the field of education that can be accepted and implemented in Indonesia. The education sector policies, such as: implementation of online learning for all levels of education; free internet credit quota assistance to all students and educators at all levels of education; financial assistance to teachers and education personnel working in the education sector; modification of the learning curriculum that prioritizes the use of technological devices. All policies issued by the Indonesian Government have the full support of the Parliament, and the budget issued also comes from the State Revenue and Expenditure Budget. On March 24, 2020 the Minister of Education and Culture of the Republic of Indonesia issued Circular Letter Number 4 of 2020 concerning Implementation of Education Policies in an Emergency for the Spread of COVID, in this circular explaining that the learning process is carried out at home through online / distance learning which is carried out to provide experience meaningful learning for students. The learning process at home is more focused on life skills education, including regarding the Covid-19 pandemic. The Minister of Education and Culture collaborates with various parties to conduct online learning. Some parties that focus on developing an online education system are Google Indonesia, Class Smart, Microsoft, Quipper, Ruangguru, Sekolahmu, and Zenius, while the Ministry of Education and Culture itself also has its own learning portal, namely the Learning House.

Indonesia is a large archipelago country, and has a total number of schools are 307.655, of which many are located in remote areas spread across 34 provinces in Indonesia, where access to transportation and telecommunication is still very limited. Not to mention the lack of technological literacy for teachers and 
students in remote areas. During its development during the Covid-19 Pandemic, dynamics emerged from various regions in Indonesia, especially with regard to the implementation of online learning. Many areas and schools in remote areas are not ready. This is because there is still very limited understanding of online learning and also the use of technological devices during the learning. Not to mention that there are still many children and parents who are not familiar with cellphones, so this condition makes the dynamics of the online learning process in remote areas in Indonesia a new thing that needs to be examined properly and wisely.

Leaders from all provinces and districts in Indonesia are trying to translate the policies of the Central Government and the Ministry of Education and Culture to be able to provide a legal umbrella for local policies in the online learning process in the regions. A number of policies in the regions have also emerged and remain under coordination and monitoring of the Central Government. However, no matter how good and ideal the policies are, if conditions in remote areas are not ready then it still creates uncertainty in their implementation and also creates turmoil. Even today, the Government of Indonesia is still trying to find innovative solutions and policies that are relevant for the State and the region so that during the Covid-19 Pandemic students can still get their right to learn.

With regard to this condition, the researcher tries to dig up information from various relevant literature sources, which can be useful for providing input and insight to the Indonesian Government or readers, so that even in the Covid-19 Pandemic situation, the online learning process can still take place with a strategy. and in different ways, teachers can carry out their duties properly and students still have the right to learn.

\section{Method}

This literature review has the purpose to extract information from various previous research sources that are relevant to the challenges of online learning in schools, so that it can provide benefits to the Indonesian government in particular and to readers in general. This method is in line with that proposed by Denzin \& Lincoln (2017), Ward \& Delamont (2020) that appropriate academic opinion from researcher that able to give an impact to the community have to be based on relevant previous researchs and relevant literatures review.

\section{Findings}

Several relevant research results such as those conducted by Trybulkevych et al. (2021), Wu (2020), Usmanjonovna et al. (2020) found that online learning readiness is influenced by the literacy ability of its users and supporting infrastructure for fluency during the learning process. Other research found by Tuan (2020), Papay et al. (2017), Pacho (2020), Mohiuddina et al. (2021) suggests that for areas where people have a low reading culture, it greatly affects the ability to use technology as a learning tool for children, and this will also affect the ability of teachers to apply online learning strategies.

With regard to family support for children for online learning, several research results by Mathew et al. (2017), Liguori \& Winkler (2020), Kinseng (2021), Hafeez et al. (2021) suggest that parents play an important role in mentoring to children when learning online because not all children are able to use technological devices and are able to clearly accept explanations from the teacher. There is also research that discusses the role of peers in the online learning process, this is as stated in the results of research conducted by Kalyanasundaram \& Madhavi (2019), Li \& Zizzi (2018), Mohiuddina et al. (2021), Muls et al. (2020) which suggests that the existence of peers during the online learning process will make it easier for students to communicate with each other so that the material presented by the teacher can be easily accepted.

The results of research in remote areas or in rural areas conducted by Aslan \& Aybek (2019), Papay et al. (2017), Ramadhani et al. (2019), Tuan (2020), Yaman-Ortas (2019) suggest that in the modern era with development technology is fast, schools in remote areas are not yet fully ready to adapt to technology to carry out online learning, the most important thing that is felt is the lack of teachers' ability to use technology itself. In line with this, research that looks at the readiness of technology adaptation by teachers, as stated by Wang \& Hu (2019), Trybulkevych et al. (2020), Taylor et al. (2017), Polly (2017) states that in general the background of the learning process What was experienced by the teacher during previous schooling was the face-to-face learning process in class, with books that are directly in the classroom, when then the teacher has to adapt to technology, especially for online learning, the teacher is not ready, so this condition affects the lesson plan compiled by the teacher, and many things happen that teachers still need time to adapt to the use of these technologies.

With regard to online learning methods, several research results such as by Polly (2017), Schipper et al. (2019), Tuan (2020), Arifin \& Hermino (2017) suggest that teachers need to inform parents of the lesson plan every week regarding learning materials and targets to be achieved, so that students with the support of their parents can prepare themselves to take part in learning well. Regarding online learning strategies, the results of research 
by Taylor et al. (2017), Ramadhani et al. (2019), Muls et al. (2020), Mikhailovna et al. (2019) suggest that online learning can be easily accepted by students when done with a model interactive, namely by means of case-based learning or project-based learning or problem-based learning so that students will easily understand the meaning of the material presented by the teacher, and the teacher can explain the learning material based on what the students get so that the learning objectives can be achieved.

Based on all the results of the research information, several things can be found regarding the benefits of online learning, especially those that can be of concern in remote areas in Indonesia, such as: 1) the importance of the role of school principals as implementers of Government policies; 2) teachers' strategies in implementing online learning that are easily understood by students; 3) the importance of the role of parental assistance during online learning; and 4) Regional Government policy strategies for the success of online learning, especially in remote areas. These four findings will then be discussed in depth in the discussion.

\section{Discussion}

\subsection{The Importance of the Role of the Principal as Implementer of Government Policy}

In remote areas the principal is not only a leader in the school but also a community leader and agent of reform. Regarding this, the Principal must be able to act such as: 1) providing clear directions to teachers and education personnel regarding the implementation of government policies regarding online learning; 2) together with the teachers to prepare online learning lesson plans that are simple and easy for students to understand; 3 ) coordinate with local governments to provide support for online learning tools; 4) coordinate with village heads to jointly provide understanding to school committees and parents about online learning policies during the Covid-19 Pandemic; and 5) regularly monitoring and evaluating the implementation of online learning and reporting the results of the process to local governments.

In its implementation, the Principal does not have to work alone but also involves the Village Head, Community Leaders, Religious Leaders, so that together they can provide support and advice to the public in general and to parents of students to understand the importance of understanding government policies regarding online learning so that children still get the opportunity to receive learning. This is also as stated by Arifin \& Hermino (2017); Aslan \& Aybek (2019); Hartinah et al. (2020) stated that involvement with community leaders in the village in monitoring and evaluating education in the village where the school is located aims to make learning successful in schools, as well as to provide a sense of comfort in the process of improving the quality of education in their village.

However, the School Principal must also be able to provide effective directions and strategies to teachers regarding the online learning model that will be carried out. This is because not all of the community or parents of students have cellphones, and not all students are able to understand the use of cellphones as a medium of learning media. In this condition, the School Principal can at least give sufficient special time to teachers with regard to: 1) understanding the use of cellphones or learning media based on Information and Technology; 2) preparation of lesson plans that are simple and easy to understand by parents and students. The lesson plans must be given to the parents of students at least one week in advance; 3 ) determining the learning model that will be implemented so that learning objectives can be achieved. The learning model can be in the form of case-based learning, problem-based learning, or project-based learning; 4) monitoring and evaluation of student academic development; and 5) the schedule of teacher visits to several student homes to obtain input and/or evaluation from students' parents. This condition is also as stated by Hafeez et al. (2021); Hermino (2016); Kalyanasundaram \& Madhavi (2019); Nashir et al. (2020) stated that the broad insight and good competition possessed by the Principal as a leader and manager will facilitate the implementation of a policy from the State.

In this regard, the role of the Principal can be described as follows: 


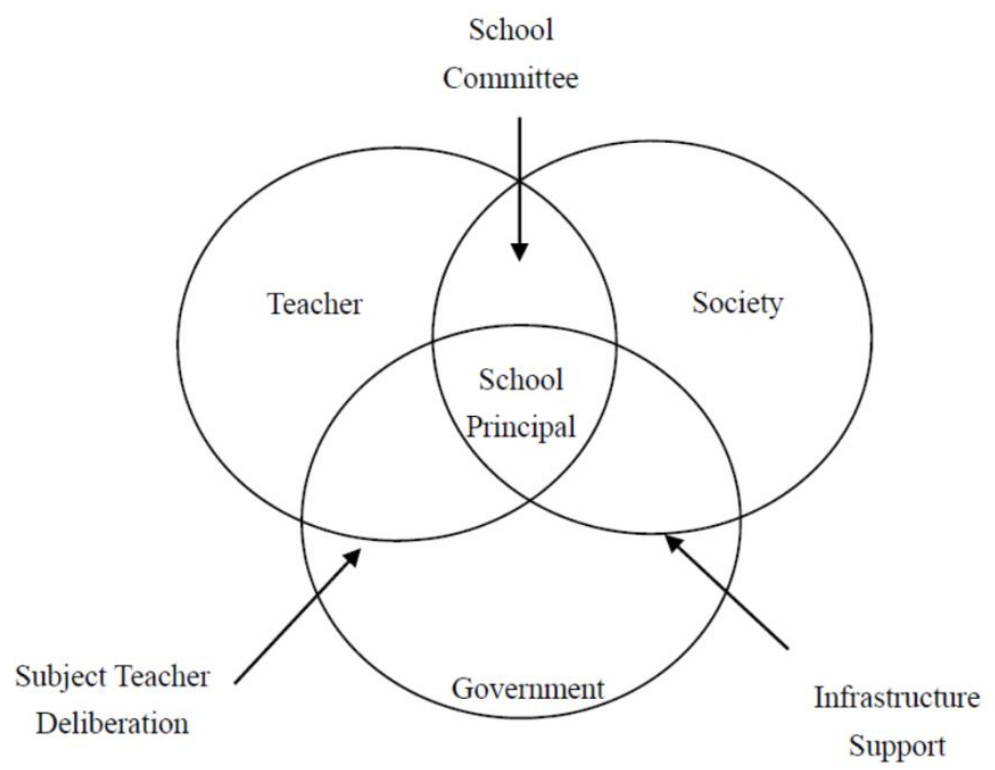

The picture above explains that the role of the School Principal for the success of online learning in remote areas is that the School Principal must be able to coordinate and communicate well with: 1) the teacher, this is intended so that the teacher feels not running alone because of support in the form of strategic steps for the process implementation of online learning; 2) community, it is intended that the community can support each other so that each parent of students as a member of the community can provide quality time and quality of communication to children through assistance during the online learning process; and 3) the government, it is intended that the government can conduct direct observation in the field to find out the implementation of online learning in schools so that it can provide strategic input to the Central Government. This condition is also as stated by: Kinseng (2019), Liguori \& Winkler (2020), Mathew et al. (2017), Pacho (2020) that whatever the government's education model policy, if the Principal can position himself to coordinate and collaborate with community members, the learning process will run well and in a pleasant atmosphere felt by the children.

Referring also to the picture above, there are 3 slices which are also the role of the Principal's strategy, namely that the School Principal must also be able to: 1) mobilize the School Committee in the function of supervising educational progress and to provide support to parents in order to pay attention to children during at home; 2) mobilizing subject teacher deliberations so that teachers can share experiences and get input for improvements and innovations in implementing learning strategies; and 3) fulfilling infrastructure support in schools and in the community referring to policies imposed by the central government so that online learning programs can be implemented according to the expected targets. This is in accordance with what was stated by Ainscow et al. (2019), Wilson (2018), Wagner (2017), Koh et al. (2018) that the School Principal as an agent of change must be able to position himself as a catalyst for all stakeholders in the education sector and be able too. mobilizing these stakeholders to jointly and with care to advance the education in the area in accordance with government policies and conditions of global development.

\subsection{Teacher Strategies in Implementing Online Learning That Is Easy for Students to Understand}

The success of implementing online learning depends on the role of the teacher. The teacher is not only limited to delivering learning material but the teacher must be able to ensure that the material being taught can be conveyed well and can be received well by the students. Many obstacles were encountered in remote areas for the implementation of this online lesson. These constraints can come from the teacher himself, from the situation of the family and society, and from the situation of the students. This condition requires teachers to be able to manage it. First, constraints from within the teacher himself. The rapid advancement of technology makes everyone have to be able to adapt, said the teacher. Teachers like it or not, like it or not, they must always keep up with the times and technology to adapt to the new world, especially online learning. Teachers must also be able to independently and work with teams to broaden their horizons and optimize their ability to adapt to technology in line with policies imposed by the government (Usmanjonovna et al. (2020); Schipper et al. (2019); Rahim \& Hulukati (2021)). With teachers being able to adapt to these technological advances, it will make it easier for teachers to carry out their duties as educators, especially in the implementation of online learning. 
Second, constraints due to the community and family situation. In remote areas, the use of technology is not the main thing because people are more concerned with working and surviving. School for children is also not a priority because for society in general, if children are able to read, write and count, then this is enough for them to find work in the future (Papay et al. (2017); Pacho (2020); Nashir et al. (2020)). This condition requires teachers to be able to approach and communicate well with the community and parents of students so that individual awareness and collective awareness are built to support children's education through providing quality time and quality of mentoring to children while at home or while the child participates in the learning process.

Third, constraints due to the situation and condition of the students. Students in remote areas are generally children who are obedient to their parents (Hartinah et al. (2020); Hafeez et al. (2021); Kinseng (2021)). They grow and thrive in a family atmosphere that requires them to work. This condition makes students generally obey only to obey the wishes of their parents. In all their limitations, they are powerless to express their desire to be able to continue to a higher level of education, this is because the family economic conditions make them have to think about survival by working rather than thinking about dreams by going to school which will take time and cost. Not to mention the challenges faced by teachers with the condition of these students are the lack of technological literacy skills, so that children will feel confused about using cellphones as a tool for learning. Regarding all of this, the teacher plays a role not only as a teacher who delivers learning material only, but teachers must be able to position themselves as parents and educators to their students, namely providing a sense of comfort and understanding of the use of technology and learning materials so that they can be accepted easily and well.

Based on the explanation above, the teacher also plays a role as an agent of change, namely: 1) changes in themselves because they have to adapt to technological developments and implement government policies; 2) play a role in providing a paradigm shift to the community that during the Covid-19 Pandemic, children still have to get their right to learn and get knowledge from teachers, namely through online learning that was previously done face-to-face. Against this, the role of the teacher as a renewal agent can be described as follows.

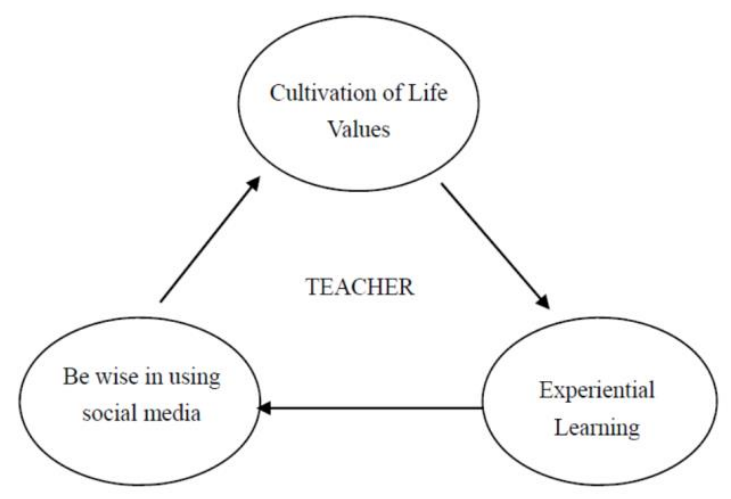

Referring to the Figure above, it can be interpreted that in the implementation of online learning, it is hoped that the teacher is able to provide learning material not only to complete the lesson plan targets, but also to provide learning messages to students regarding character education, namely: 1) students are invited to be able to interpret the values of life in the form of advice from any material delivered by the teacher. This aims to open children's insight into the faith as a provision to become human beings who know God;2) students are invited to do assignments through case-based learning, problem-based learning, or project-based learning models, so that students and teachers will collaborate for a critical thinking process by students. This experiential learning will make it easier for students to remember and understand the process of a learning material being taught by the teacher; and 3) students are invited to policy on the use of social media. This is so that students do not carelessly open sites that are not useful for themselves and are not relevant to the learning material. With regard to the three roles of teachers, this is in line with what was stated by Hermino (2016), Li \& Zizzi (2018), Mathew et al. (2017), Nastiezaie \& Musavinejad (2018), Muttaqin (2018) that in the era of global adaptation in With the rapid development of technology, the teacher also has an obligation to provide character education learning through moral values that are included in each learning material, which will be very useful for students to become good and wise individuals in the future.

\subsection{The Importance of the Role of Parental Assistance During Online Learning}

In order for the learning process to run as it should, there needs to be two-way communication between the school and the parents of students. Building communication is important so that parents understand the learning 
objectives expected by the teacher and vice versa, the teacher also understands the wishes of parents in accompanying children while studying at home. Parents' expectations for online learning include: 1) the material presented can be understood by children well; 2) the instructions for carrying out the task must be clear; 3) the tasks given are not burdensome to the child; 4) the teacher in giving explanations of the material is not too fast so that students can better understand the material; 5) receive internet quota assistance because internet quota is one of the things that is burdensome for the parents of students; 6) online learning methods can be made as attractive as possible so that students do not feel bored when participating in learning; 6) communication between students and teachers is more intense if there are obstacles; 7) the material presented is easy to understand, and the material is integrated with student life; 8) learning is carried out in a pleasant atmosphere for students; and 9) students acquire skills and character education.

With regard to these conditions, online learning at the school cannot be separated from the role of parents as learning companions. Parents have full responsibility for the success of the child's learning process. Many parents are unable to fully assist their children to study because both parents have to work, so those who accompany the children to study at home are other family members. There are also parents who cannot understand the material provided by the teacher, so as a solution parents give confidence to a special teacher who is contracted by the parent to assist the child in learning. Activities that are usually carried out by parents in accompanying children to study at home are nothing more than just checking the assignments given by the teacher to the child. In the meaning of online learning, two-way communication between parents and children will position the child in a comfortable condition and feel accompanied by the parents, so that the child will remain enthusiastic about learning. With this regard, as stated by Lilawati (2020); Basilaia \& Kvavadze (2020); Liguori \& Winkler (2020); Mohiuddina et al. (2021); Pacho (2020) states that parents 'interest and awareness to accompany their children during online learning is determined by several factors such as education, occupation and parents' income. This is also in line with what was stated by Rahim \& Hulukati (2021); Trybulkevych et al. (2021); Wu (2020); Usmanjonovna et al. (2020) stated that the quality of time and quality of assistance by parents to children during online learning greatly determines the level of children's understanding in receiving learning material, for this condition parents who have awareness of the importance of education for children will provide sufficient time to provide assistance, and this is also influenced by the economic welfare in the family.

\subsection{Local Government Policy Strategies for Successful Online Learning, Especially in Remote Areas}

There are at least three strategic steps that can be taken by the Government to support the implementation of online learning in Indonesia, even after the COVID-19 pandemic ends. Such support includes: first, instilling a mindset about new ways of learning. With the current development of technology and the internet, the learning process can occur anytime, anywhere, and with anyone without space and time boundaries. Hafeez et al. (2021); Basilaia \& Kvavadze (2020); Aslan \& Aybek (2019). Regarding this, the education climate in Indonesia must be adaptive to the development of global dynamics and technology. Regarding this, the Indonesian Ministry of Education and Culture must be able to communicate to the public to realize the new demands of the education system that are not sufficiently taught only through formal classes.

Second, preparing regulations for the development of digital learning resources. The use of any platform massively and openly and which is effective for the implementation of online learning is one of the most effective trends in online learning practices today. The use of the platform for learning must of course be socialized to users in schools, so that school students can know and use it properly and optimally for the success of the learning process (Liguori \& Winkler (2020); Kinseng (2021); Kalyanasundaram \& Madhavi (2019)). Third, print adaptive teaching staff in learning technology. This is related to the ability of educators in designing learning strategies to be very important because it is a determining factor for the success of the implementation of online learning. The ability of the educator or teacher so that the material being taught can be conveyed properly to students, and students can receive the learning material properly and optimally, the teacher needs to have skills in designing, organizing, and controlling interactive learning activities and materials to achieve learning objectives (Ainscow et al. (2019); Hartinah et al. (2020); Mathew et al. (2017); Nastiezaie \& Musavinejad (2018); Adxamovna (2020)). The thing that must be avoided regarding the role of the teacher is that the Government must be able to ensure that teachers do not only carry out online learning tasks without providing feedback and assume that when the learning material has been delivered to students, they consider the task to be completed without planning a long-term learning strategy, or more. to be precise it merely transfers one-way learning from what is usually in the classroom, to the 'cloud'.

In this regard, the local government strategy to implement central government policies in order to make online learning successful, especially in remote areas can be illustrated in the following diagram below. 
Referring to the diagram below, it can be interpreted that the role of local government in issuing policies to make success in implementation of the online learning and the importance of understanding family and society towards the future of children, it is necessary to get a mutual understanding between the village, community, family, and school, so that the policy is accepted. by all citizens, can be understood and implemented properly, so as to produce an impact of the goals to be achieved from the policy. This is also in line with what was stated by White \& Warfa (2011); Yaman-Ortas (2019), Hung (2020) stated that the implementation of policies on the quality of education and the interest of children in school must be supported by all parties in society and cannot be left only to schools, so a collective understanding is needed to support a better future for children
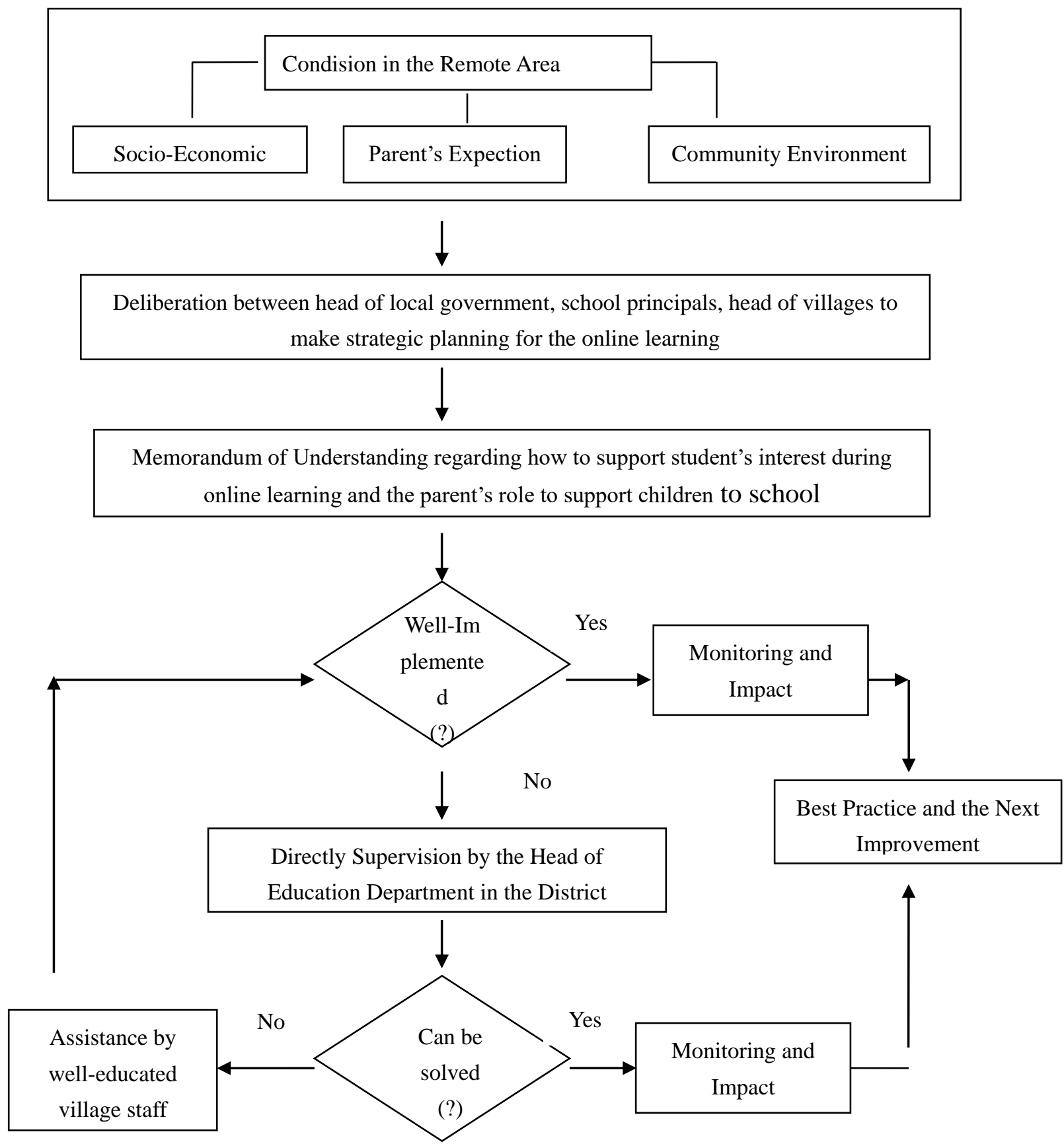


\section{Recommendations}

There are several recommendations as follows: first, the government needs to adjust the implementation of online learning according to local conditions. This is because internet access in remote areas is still quite difficult, so it is possible that the delivery of learning materials can be done via radio. Second, forming regional work groups to provide guidance on online learning strategies. The task force in the area is to assist local governments in providing financial assistance outside of the School Operational Assistance provided by the Central Government, and access to recording studios and equipment for schools and teachers, if teachers have to prepare learning materials that must be recorded in advance, or by by using youtube.

Third, develop a monitoring and evaluation framework for the use of School Operation Assistance funds in the context of implementing online learning. This monitoring or supervision not only helps ensure that funds are used in accordance with the direction of the Ministry of Education and Culture, but also to identify areas where assistance is most needed. Fourth, provide broader autonomy to school principals to issue internal school policies in implementing online learning. These internal policies can range from the use of School Operational Assistance funds received from the Central Government, to strategies to collaborate with local governments, village heads, community leaders, religious leaders to jointly pay attention to children in participating in online learning.

Fifth, equip teachers with skills to carry out online learning. For the successful adoption of distance learning, teachers have not only basic technology skills (such as using computers and being connected to the internet), but also knowledge for using recording devices and software, as well as methods for delivering lessons without face-to-face interaction. These skills will be required when it comes to using platforms for online learning. Sixth, maintaining government partnerships with the private sector in the education sector. The partnership between the government and the private sector, especially in technology service providers, is in the provision of infrastructure to support online learning. Such partnerships could include the provision of telecommunications equipment and hardware to equip all schools, especially those located in remote areas, with internet connections, information technology and communication facilities, and skills development programs for teachers. Seventh, support underprivileged students to return to school. In this regard, the Central and Regional Governments take additional steps to ensure that students from disadvantaged families and eldest children who have to help their parents work because they come from poor families, where they are potentially the most vulnerable to dropping out of school, can remain enrolled in school. Against this, the strategy adopted by the teacher is home visits to them so that direct learning can be carried out.

\section{Conclusion}

The rapid spread of the Covid-19 pandemic has caused disruption to the education sector in Indonesia especially in remote areas where around 45 million students are unable to continue their learning activities at school. The Ministry of Education and Culture needs to consider the implementation of online learning tailored to the different characteristics of regions in Indonesia. Online learning has added to barriers for students who are already having difficulty accessing education in remote areas. In this regard, diversification of delivery media other than using the internet is considered, such as using radio or using postal services for areas with low internet connectivity.

There is awareness and joint involvement between the Central and Local Governments, Principals, Teachers, the community, and parents to jointly provide attention and support for children to actively participate in online learning will make children in a comfortable condition and remain excited to receive learning from teachers and a good future.

\section{References}

Adxamovna, M. N. (2020). Why is Critical Thinking so Important in Ccademic Life? International Journal of Psychosocial Rehabilitation, 24(3), 282-285. https://doi.org/10.37200/IJPR/V24I3/PR200780

Ainscow, M., Chapman, C., \& Hadfield, M. (2019). Changing Education Systems: A Research-based Approach. Routledge.

Arifin, I., \& Hermino, A. (2017). The Important of Multicultural Education in Schools in the Era of ASEAN Economic Community. Asian Social Science, 13(4). https://doi.org/10.5539/ass.v13n4p78

Aslan, S., \& Aybek, B. (2019). Testing the Effectiveness of Interdisciplinary Curriculum-Based Multicultural Education on Tolerance and Critical Thinking Skill. International Journal of Educational Methodology, 6(1), 43-55. https://doi.org/10.12973/ijem.6.1.43 
Basilaia, G., \& Kvavadze, D. (2020). Transition to Online Education in Schools during a SARSCoV-2 Coronavirus (COVID-19) Pandemic in Georgia. Pedagogical Research, 5(4). https://doi.org/10.29333/pr/7937

Denzin, N. K., \& Lincoln, Y. S. (2017). The SAGE Handbook of Qualitative Research (5th ed.). SAGE.

Hafeez, M., Ajmal, F., \& Kazmi, Q. A. (2021). Challenges Faced by the Teachers and Students in Online Learning. International Journal of Innovation, Creativity and Change, 15(2), 325-346. Retrieved from https://www.ijicc.net/images/Vol_15/Iss_2/15240_Hafeez_2021_E1_R.pdf

Hartinah, S., Suharso, P., Umam, R., Syazali, M., Lestari, B. D., Roslina, R., \& Jermsittiparsert, K. (2020). Teacher's Performance Management: The Role of Principal's Leadership, Work Environment and Motivation in Tegal City, Indonesia. Management Science Letters, 9(14), 1-12. https://doi.org/10.5267/j.msl.2019.7.038

Hermino, A. (2016). ASEAN Economic Community in the Pespective of Transformational Leadership in School. International Journal of Education and Research, 4(6), 401-416. Retrieved from http://www.ijern.com/June-2016.php

Hung, J. (2020). Systematic Review on How the Delivery of Vision Care Policies Affects Students' Academic Performance and Mental Health. Asian Social Science, 16(7). https://doi.org/10.5539/ass.v16n7p94

Kalyanasundaram, P., \& Madhavi, C. (2019). Students' Perception on E-Learning - A study of Online Certificate Courses. International Journal of Psychosocial Rehabilitation, 23(1), 302-306. https://doi.org/10.37200/IJPR/V23I1/PR190239

Kinseng, R. A. (2021). Covid-19 and Social Change in Indonesia. International Journal of Innovation, Creativity and Change, 15(2), 159-174. Retrieved from https://www.ijicc.net/images/Vol_15/Iss_2/15207_Kinseng_2021_E1_R.pdf

Koh, J. H. L., Chai, C. S., \& Natarajan, U. (2018). Developing Indonesia teachers' technological pedagogical content knowledge for 21st century learning (TPACK-21CL) through a multi-prong approach. Auckland: Journal of International Education and Business, 3(1), 11-33.

Li, S., \& Zizzi, S. (2018). A Case Study of International Students' Social Adjustment, Friendship Development, and Physical Activity. Journal of International Students, 8(1), 389-408. https://doi.org/zenodo.1134317

Liguori, E., \& Winkler, C. (2020). From Offline to Online: Challenges and Opportunities for Entrepreneurship Education Following the COVID-19 Pandemic. SAGE Publications Sage CA: Los Angeles, CA.

Mathew, P., Mathew, P., \& Peechattu, P. J. (2017). Reflective Practice: A Means to Teacher Development. Asia Pacific Journal of Contemporary Education and Communication Technology, 3(1), 126-131.

Mikhailovna, C. E., Sobakina, T. G., Nguyen, P. T., Nguyen, Q. L. H. T. T., \& Huynh, V. D. B. (2019). Studying Humanitarian Disciplines using Role Games at Higher Educational Establishments. International Journal of Psychosocial Rehabilitation, 23(1), 37-44. https://doi.org/10.37200/IJPR/V23I1/PR190211

Mohiuddina, M., Azadb, M. S. A., \& Su, Z. (2021). Information and Communication Technology (ICTs) and Organizational Culture for Knowledge Sharing Strategy: Case Study of a Center for Continuing Education. International Journal of Innovation, Creativity and Change, 15(21), 86-108. Retrieved from https://www.ijicc.net/images/Vol_15/Iss_2/141256_Mohiuddin_2021_E_R.pdf

Muls, J., Thomas, V., De Backer, F., Zhu, C., \& Lombaerts, K. (2020). Identifying the Nature of Social Media Policies in High Schools. Education and Information Technologies, 25(1), 281-305. https://doi.org/10.1007/s10639-019-09971-7

Muttaqin, T. (2018). Determinants of Unequal Access to and Quality of Education in Indonesia. The Indonesian Journal of Development Planning, 2(1), 1-20.

Nashir, I. M., Esti, D., Ma'arof, N. N. M. I., Azman, M. N. A., \& Khairudin, M. (2020). The Future of Leadership Framework in Malaysia Education Systems. International Journal of Psychosocial Rehabilitation, 24(3), 617-625. https://doi.org/10.37200/IJPR/V24I3/PR200818

Nastiezaie, N., \& Musavinejad, S. (2018). Predicting the Effectiveness of School Principals Based on Fiedler's Leadership Model. The New Educational Review, 51(1), 184-191. https://doi.org/10.15804/tner.2018.51.1.15

Pacho, T. O. (2020). Impact of Globalisation on African and Its Implication to Education. Social Sciences, 
Humanities and Sustainability Research, 1(1). https://doi.org/10.22158/sshsr.v1n1p81

Papay, J. P., Bacher-Hicks, A., Page, L. C., \& Marinell, W. H. (2017). The Challenge of Teacher Retention in Urban Schools: Evidence of Variation from a Cross-site Analysis. Educational Researcher, 46(8), 434-448.

Polly, D. (2017). Providing School-based Learning in Elementary School Mathematics: The Case of a Professional Development School Partnership. Teacher Development, 21(5), 668-686.

Rahim, M., \& Hulukati, W. (2021). Development of Handbooks of Guidance and Counseling to Enhance Elementary School Teachers' Competence in Cultivating Students' Creativity. European Journal of Educational Research, 10(2), 657-670. Retrieved from https://www.eu-jer.com/EU-JER_10_2_657.pdf

Ramadhani, R., Umam, R., Abdurrahman, A., \& Syazali, M. (2019). The Effect of Flipped-Problem Based Learning Model Integrated With LMS-Google Classroom for Senior High School Students. Journal for the Education of Gifted Young, 7(2), 137-158. https://doi.org/10.17478/jegys.548350

Schipper, T. M., de Vries, S., Goei, S. L., \& van Veen, K. (2019). Promoting a Professional School Culture through Lesson Study? An Examination of School Culture, School Conditions, and Teacher Self-efficacy. Professional Development in Education, 46(1), 112-129. https://doi.org/10.1080/19415257.2011634627

Taylor, J. A., Roth, K., Wilson, C. D., Stuhlsatz, M. A. M., \& Tipton, E. (2017). The Effect of an Analysis-of-Practice, Videocase-based, Teacher Professional Development Program on Elementary Students' Science Achievement. Journal of Research on Educational Effectiveness, 10(2), 241-271.

Trybulkevych, K. H., Shchegoleva, T. L., Gruba, T. L., Gula, L. V., \& Zoriy, Y. B. (2021). Ethics of Communication as an Important Component of Teacher Self-Branding in the Settings of the Digital Environment. European Journal of Educational Research, 10(2), 641-655. Retrieved from https://www.eu-jer.com/EU-JER_10_2_641.pdf

Trybulkevych, K. H., Zaitseva, A. V., Lupak, N. M., Dychkivska, I. M., \& Bortniuk, T. Y. (2020). The Influence of Social Reflection to Enhance the Efficiency of Professional Communication of the In-service Teachers in the Settings of Methodical Work. Applied Linguistics Research Journal, 4(9), 182-189. https://doi.org/10.14744/alrj.2020.87894

Tuan, N. D. (2020). Opportunities to Access to General Education of Children Living in Poverty Families in Ethnic Minority in Vietnam Nowadays. Asian Social Science, 16(6). https://doi.org/10.5539/ass.v16n6p43

Usmanjonovna, A. M., Najimovna, O. L., Tashpulatovna, G. N., \& Sabirovna, N. K. (2020). Formation of Scientific Outlook and Mental Education of Students. International Journal of Psychosocial Rehabilitation, 24(3), 304-310. https://doi.org/10.37200/IJPR/V24I3/PR200783

Wagner, D. A. (2017). Learning as Development. Rethinking International Education in a Changing World. Routledge.

Wang, H., Pi, Z., \& Hu, W. (2019). The Instructor's Gaze Guidance in Video Lectures Improves Learning. Journal of Computer Assisted Learning, 35(1), 42-50. https://doi.org/10.1111/jcal.12309

Ward, M. R. M., \& Delamont, S. (2020). Handbook of Qualitative Research in Education (2nd ed.). Elgar.

Wilson, J. M. (2018). The Human Side of Changing Education: How to Lead Change with Clarity, Conviction, and Courage. Corwin.

Wu, S. Y. (2020). Incorporation of Collaborative Problem Solving and Cognitive Tools to Improve Higher Cognitive Processing in Online Discussion Environments. Journal of Educational Computing Research, 58(1), 249-272. https://doi.org/10.1177/0735633119828044

Yaman-Ortas, B. (2019). According to Whom, Who is Who?: Perceptions Regarding Cultural, Educational Diversity, and Othering (Amsterdam, the Netherlands Example). European Journal of Educational Research, 8(4), 965-981. Retrieved from https://www.eu-jer.com/EU-JER_8_4_965.pdf

\section{Copyrights}

Copyright for this article is retained by the author(s), with first publication rights granted to the journal.

This is an open-access article distributed under the terms and conditions of the Creative Commons Attribution license (http://creativecommons.org/licenses/by/4.0/). 